\title{
TOTAL QUALITY MANAGEMENT: ORIGINS AND EVOLUTION OF THE TERM
}

Angel R. Martínez-Lorente

Assistant professor of the Department of Economia de la Empresa, University of Murcia, Spain.

E-mail: arml@plc.um.es

A. R. Martínez earned a doctorate in economics and business sciences from the University of Murcia. He has 7 years teaching experience in financial and operations management.

Frank Dewhurst

Lecturer in Operational Research and Quantitative Methods

Director of IT

Manchester School of Management, UMIST

E-mail: Frank.Dewhurst@umist.ac.uk

Frank Dewhurst has over 20 years teaching experience in QM and OR. He also has substantial consultancy experience with external bodies and companies.

Barrie G. Dale

United Utilities Professor of Quality Management at the University of Manchester Institute of Science and Technology. Academician of the International Academy for Quality.

E-mail: Barrie.Dale@umist.ac.uk

B. G. Dale has written ten books on TQM and published over 300 papers on the subject. He is Editor of The International Journal of Quality \& Reliability Management. 


\title{
TOTAL QUALITY MANAGEMENT: ORIGINS AND EVOLUTION OF THE TERM
}

\begin{abstract}
The focus of this paper is to trace the origins of the term TQM and clarify the different definitions employed by academics and practitioners. Feigenbaum and Ishikawa are perhaps the greatest contributors to the development of the term. The other recognised quality management gurus such as Crosby, Deming and Juran have shaped the dimensions, practices and mechanism which underpin the concept, but it is noted that neither of these three actually use the TQM term. TQM started to be used in the mid 1980's and only become a recognised part of the quality-related language in the late 1980's. The paper also analyses the key dimensions of TQM and traces their origins.
\end{abstract}

Key words: Total Quality Management, Definition, Evolution, Dimensions.

\section{INTRODUCTION}

In the global marketplace increased levels of competition have resulted in quality becoming of increasing importance to organisations and consequently Total Quality Management (TQM) has become a key management issue. A considerable number of companies are applying TQM and the topic is the subject of many books and papers. As the end of the 20th century approaches, TQM appears to be a wellaccepted system of management. Yet two decades ago the term was not used. What has been the process of development of TQM theory and practice and when and why did the term come into being? This paper attempts to answer these questions. 
Before discussing the origins of TQM it is necessary to examine definitions of the term. This is not an easy task as almost every writer on the subject has their own definition, by and large devising it to suit their own beliefs, prejudices and business and academic experiences. To some degree this is also true in the organisations which have introduced a TQM approach to managing the business. The result is a proliferation of unique definitions which confounds comparisons and adds to the difficulties of understanding and analysis. Even with the publication of an international definition of TQM in ISO 8402(1994) there is ample evidence that writers and researchers do not stick to this definition and create their own unique offering. Moreover, as Hackman and Wageman (1995) state, a large number of interventions not related with TQM are being encompassed under the TQM banner; this further complicates the issue of definition and understanding. Despite the divergence of views on what constitutes TQM there are a number of common elements running through the various definitions (e.g. top management support, customer and supplier relationships and employee involvement). Several writers have tried to define the different dimensions that shape TQM, including Ahire et al. (1996), Dale et al. (1994), Flynn et al. (1994) and Saraph et al. (1989). Table 1 contains an analysis by the authors of the common dimensions.

In this paper the discussion about the development of TQM begins with a brief historical review of the different stages that preceded the birth of TQM. A comparative analysis of the Japanese approach to quality management and an examination of Feigenbaum's (1961) concept of Total Quality Control is made, these constitute two of the major inputs into the development of TQM. The visions of the quality management gurus are also examined. 


\section{AN HISTORICAL PERSPECTIVE}

Powell (1995) makes the points that: “TQM's origins can be traced to 1949, when the Union of Japanese Scientists and Engineers formed a committee of scholars, engineers, and government officials devoted to improving Japanese productivity, and enhancing their post-war quality of life” and "American firms began to take serious notice of TQM around 1980.”

It can be argued that many of the TQM dimensions outlined in Table 1 were being applied by organisations before the TQM movement appeared; consequently, it is not easy to establish the exact date of birth of the term TQM. Stuelpnagel (1993) considers that in Ford and Crowter's book "My Life and Work", published in 1926, the origins of TQM can be found. Nevertheless, it is clear that the term and the philosophy as a whole appeared around the mid 80’s. Bemowski (1992) states that the term TQM was initially coined in 1985 by the Naval Air Systems Command to describe its Japanese-style management approach to quality improvement.

Perhaps, the main reason for the origin of the term TQM could be a substitution in the previously used term of Total Quality Control (TQC), the word "control” by "management" with the reasoning that quality is not just a matter of control, it has to be managed. This is reinforced by Deming's (1982) view that sampling inspection should be suppressed and also by Crosby (1979) who makes the point that control is not necessary when a zero defects level is achieved. The term “control” is sometimes understood as meaning control over the workforces activities, and this is clearly not the aim of TQM (Godfrey et al., 1997).

In the USA the development of quality management resulted from the penetration of its markets by Japanese products which started in the 70s, together with the impact of the writings of Crosby, Deming, Feigenbaum and Juran. Consequently, 
companies and academics studied the works of these authors and others, such as Ishikawa, and, integrating their approaches with quality management, gave rise to the concept of TQM. This movement was exported to other countries, the UK being one of the first.

Dale, who started his research in quality management back in 1981, believes that the term TQM arose in the UK from the activities of the Department of Trade and Industry National Quality Campaign which was launched in 1983 and the pioneering work of organisations such as IBM. He relates a discussion with John MacDonald (one of the stalwarts of the UK quality management and the first Managing Director of Crosby Associates UK Ltd.) who mentioned that around mid 1986 he was using the term TQM in his cross-Atlantic communication with Philip Crosby, who responded with the retort "what is TQM"? It is also worth mentioning that in the early to mid eighties the use of quality-related terms and acronyms was nothing like as pronounced as it is today.

Table 2 has been created from an analysis of the ABI-INFORM data base, which include brief summaries of business articles published since 1986. The number of references with the terms TQM, Quality Management (QM) and Total Quality (TQ) included in them has been searched. As Table 2 shows, the number of papers including the term TQM in 1986, 1987 and 1988 is small, which confirms the view already expressed that the term only started to be used in the literature since mid 1980. It can be seen that at the beginning of the 90s, the use of the term was already widespread, reaching a peak in 1993. Since then, the number of papers using the term has been in decline, although maintaining some importance in relation to volume of material. It is the authors' opinion that this decrease in the number of papers is because TQM is widely known and accepted and is not attracting the attention from 
writers as it once did. However, some of the most recent incorporations into TQM, such as benchmarking and self assessment, have been the subject of further treatment in the management literature.

If the origins of the TQM dimensions in Table 1 are traced and analysed, the following key points emerge:

a) Those related with workforce management and the need for top management leadership have their origins in the USA, arising from the Hawthorne studies (Roethlisberger and Dickson, 1939), the works of Maslow (1954) and McGregor (1960) and, more recently, that of Ouchi (1981).

b) With respect to process flow management, SPC has its roots in the USA with Shewhart (1931) and the UK with Dudding (BS 600 (1935)). On the other hand, mistake proofing systems are a Japanese idea (Shingo, 1986), as is the importance of cleanliness and organisation of tools and housekeeping using the 5s and CANDO (cleanliness, arrangement, neatness, discipline and orderliness) principles.

c) The concern about consumers needs has been of inherent interest to marketing theorist since it first appeared, the main development work on this subject has been conducted in the USA. The increase in competition and demanding consumers have been the main reason for companies treating this need to listen to "customers voices" in a serious manner.

d) Most of the recommendations about design processes have arise from observation of Japanese procedures and best practices. Taguchi methods (Taguchi, 1986) were developed by Genichi Taguchi, a Statistician and electrical engineer who was involved in rebuilding the Japanese telephone system. Quality function deployment (QFD) methods were also developed in Japan, but, as with the case of many other 
Japanese management tools and techniques, they have been popularised world-wide by North American writers such as Hauser and Clausing (1988).

e) The grounds of the supplier relationship dimension can be found mostly in JIT theories, which were first developed in Toyota (Monden, 1983).

f) The role of the quality department have been widely analysed by American writers such as Feigenbaum (1991) and Juran et al. (1974).

g) Benchmarking was first developed in Xerox, an American company (Tucker et al., 1987) and popularised by the work of Camp (1989).

A brief resume of the historical events that have influenced the development of TQM theory and practice is provided in Table 3, indicating a gradual emergence of TQM. The use of statistical methods and the fundamentals of the system of workforce management began to be developed early in the century and Japan developed its TQM approach gradually from the end of the second world war. At the end of the 70's and the beginning of the 80's, Japanese pressure and the success of some American writers created a general concern about the focus on quality management in the USA, and from this country to the rest of the world. The publication of the Malcolm Baldridge National Quality Award and other similar awards in other countries was the official recognition of the importance of TQM.

\section{COMPARISONS BETWEEN JAPANESE AND AMERICAN TQC}

Feigenbaum $(1956,1961)$ was the first author who used the term TQC. In his first book on TQC (Feigenbaum, 1961) (a revision of the book original published under the title “Quality Control” in 1951), he defined TQC as "an effective system for integrating the quality-development, quality maintenance, and quality-improvement efforts of the various groups in an organisation so as to enable production and service 
at the most economical levels which allow for full customer satisfaction”. He considered that "control must start with the design of the product and end only when the product has been placed in the hands of a customer who remains satisfied”. In this book Feigenbaum recognised that all departments in a company have some responsibility for the achievement of quality, as it was originally perceived by Feigenbaum. However, TQC did not include many of the elements (e.g. supplier developmental relationships, people empowerment and teamwork) that are now considered part of the TQM concept.

Japanese companies have developed their own approach to TQC, based on the teachings of Deming and Juran, shaping it to suit their own culture and operating environment along with the development of a new set of tools, techniques and operating systems. In the authors’ opinion Ishikawa was mainly responsible for shaping Japanese style TQC. His definition of TQC or Company Wide Quality Control (CWQC) is: “Quality control consists of developing, designing, producing, marketing, and servicing products and services with optimum cost-effectiveness and usefulness, which customers will purchase with satisfaction. To achieve these aims, all the separate parts of a company must work together” (Ishikawa, 1990).

Analysing Feigenbaum's and Ishikawa's definitions, it can be seen that there are no major differences. However, Ishikawa (1985) is of the view that the difference between CWQC and Feigenbaum's approach is that, whilst Feigenbaum advocates that TQC is conducted essentially by QC specialists, CWQC has never been an exclusive domain of such specialists. Indeed analysing the work of Feigenbaum (1961), it can be seen that the focus on the participation of employees is weak and the task of improving quality is given to managers. According to Garvin (1988), the term CWQC was introduced in Japan in 1968, some ten years after Feigenbaum introduced the 
term TQC. Garvin (1988) states that "CWQC includes four principal elements: the involvement of functions other than manufacturing in quality activities; the participation of employees at all levels; the goal of continuous improvement; and careful attention to customers' definitions of quality”. He considers the confusion between CWQC and TQC to be widespread because "whereas some experts use the terms interchangeably others see CWQC as a more advanced and comprehensive concept”. It is interesting that in Japan for the last three years there has been discussion of the differences between TQC and TQM and the latter term is now starting to be used by both organisations and academics.

The differences in Japanese and Western views may relate to differences in culture, politics and company philosophy. Ishikawa (1989) identified fourteen areas of difference between Japan and the West, including:

"1. In the United States and Western Europe, great emphasis is placed on professionalism and specialisation; “QC only for QC specialists”.

2. In the United States and Western Europe, great emphasis is placed on the Taylor system.

3. The pay system in the United States and Western Europe is based on merit (to motivate people by money alone). Japan uses a system of seniority and ranking.

4. High turnover rates and layoffs are found in the West; Japan has a lifetime employment system.

5. Relationships with subcontractors - $70 \%$ of a product's manufacturing costs are contributed by outside suppliers in Japan, and only 50\% in the United States. Subcontractors are treated as friends not enemies as in the case in the west.

6. Old-style capitalism vs. democratisation of capital: short-term profits vs. longterm profits.” 
These six differences, together with political and cultural differences have meant that the TQM approaches in Japan, the USA and Europe are different. Although the Japanese model has a proven successful track record, the existence of differences is not necessarily an indicator that the Western model is inferior, since, as Ishikawa (1989) advocates, companies must adapt CWQC to the country or company according to differences of social background. In the last decade numerous success stories have emerged of TQM applications in Europe and America. Abo (1995) demonstrates how the management of manufacturing systems of Japanese multinationals is different in Asia, Europe and the USA. These differences indicate that Japanese multinationals have had to adapt their management systems to the different conditions of countries. On the other hand, Ebrahimpour (1988) and Garvin (1986) examine how Japanese companies operating in the USA have successfully applied some of the features of the quality management approach they employ in Japan.

The authors' consider that the way in which TQM has developed from the Japanese and Feigenbaum's concepts has been the inclusion of appropriate management theory as demonstrated by the TQM dimensions given in Table 1 . Examining the ISO 8402(1994) definition of TQM, it is clear that TQC and CWQC are essentially TQM. However, differences in its application in companies, due partially to the differences that Ishikawa (1989) identified, still exist and this will always be the case.

\section{TQM: VIEWS OF THE QUALITY MANAGEMENT GURUS}

Crosby, Deming, Feigenbaum, Ishikawa and Juran can be considered the most important gurus of the quality management movement. However, this does not mean that their approaches are the same. The views of Feigenbaum and Ishikawa have 
already been considered and the focus of attention is now turned to Crosby, Deming and Juran.

Deming achieved great popularity in 1980 after the NBC television documentary about success in Japan where he was considered a key element. Although Deming maintained a contrary position with respect to some of the TQM elements (e.g., zero defects and quality costing) (Deming, 1982, 1986), a considerable number of authors (e.g. Davis and Fisher, 1994, Grandzol and Traaen, 1995, Milakovich, 1991, Pollock, 1993, Rago, 1994, Schay, 1993 and Tamimi and Gershon, 1995) consider him as one of the main supporters of the TQM concept. English (1996) considers that Juran is related with TQM and Drensek and Grubb (1995) and English (1996) also consider that Crosby is a TQM theorist.

Hackman and Wageman (1995) state that Deming, Ishikawa and Juran can be considered the founders of the TQM philosophy, "since TQM drinks in their works". Surprisingly, they do not mention Feigenbaum, the originator of the term TQC, which as shown in this paper has many similarities with the term TQM. However, they also consider that "what many organisations are actually implementing is a pale or highly distorted version of what Deming, Ishikawa and Juran laid out”.

Juran does not use the term TQM in his main book "Quality Control Handbook” (Juran et al., 1974, Juran and Gryna, 1988) nor in “Juran on Planning for Quality” (Juran, 1988). In “A History of Managing for Quality” he uses less than one page to explain TQM and considers that the best definition of TQM can be found in the "criteria used to judge the applications for the United States' Malcolm Baldridge National Quality Award” (Juran, 1995). Neither does Crosby in "Quality is Free” (1979), nor in “Quality without tears” (1987) nor in "Completeness. Quality for the 21st century” (1992). 
A brief comparison of the ideas of these five quality gurus in relation to the TQM dimensions that were introduced in Table 1 is made in Table 4. It can be seen that the need of top management support and the importance of customer relationship is shared by all. Benchmarking is not considered by any of them, perhaps because this technique came to the fore when they already had a well-proven approach to quality management. Deming and Crosby focus their approaches in the production process without referencing the design process; however, their views are different, since Crosby defends the achievement of zero defects through employees commitment, whereas Deming criticises slogans and exhortations to achieve zero defects. Both the supplier relationship, the quality data and reporting dimensions are not considered in any detail by the five authors, but important differences do not appear to exist. Ishikawa's approach is more employee focused than the other four, which consider that quality management needs to be guided mainly by managers. Juran, Ishikawa and Feigenbaum devote chapters of their books to sampling inspection, whereas Deming criticises this technique and Crosby considers that it is not necessary in a zero defects environment.

\section{CONCLUSIONS}

This paper has considered the evolution of the elements, practices and mechanisms that define TQM. It has been shown that, whilst the term TQM only began to be popularised in the second half of the 80 s, many of the elements that have shaped it were developed early, during the 1950 to 1970s. Most theoretical developments in the advancement of the concept have been made in the USA whereas Japan has held the initiative in terms of application. 
The paper also indicates a lack of a total agreement about how to apply TQM, as supported by the differences in the views of the leading quality management gurus. For example, the need for focus on workforce management is widely accepted but the proposed ways in which to apply this form of management are different. Other elements of TQM, such as benchmarking and supply chain management, are not considered in any detail by the shapers of the TQM concept.

Differences in the application of TQM amongst different countries also appear to exist. Since the culture of the company influences the approach to the application of TQM, different countries with different cultures apply TQM in different ways. However, as we approach the end of the century, economies and societies are becoming increasingly inter-related and these differences are diminishing.

\section{REFERENCES}

Abo, T. (1995), “A comparison of Japanese 'hybrid factories' in U.S., Europe and Asia”, Management International Review, Vol. 35, No. 1, pp. 79-93.

Ahire, S. L., Golhar, D. Y. and Waller, M. A. (1996), "Development and validation of TQM implementation constructs” Decision Sciences, Vol. 27, No. 1, pp. 23-56.

Bemowsky, K. (1992), “The quality glossary”, Quality Progress, Vol. 25, No. 2, pp. 18-29.

BS 600 (1935), The application of statistical methods to industrial standardisation and quality control, British Standards Institution, London.

Camp, R. C. (1989), Benchmarking: the search for industry best practices that lead to superior performance, Quality Press, Milwaukee, Wis.

Crosby, P. B. (1979), Quality is free, McGraw-Hill, New York.

Crosby, P. B. (1987), Quality without tears, McGraw-Hill, Singapore.

Crosby, P. B. (1992), Completeness. Quality for the 21st century, Dutton, USA.

Dale, B. G., Boaden, R. J. and Lascelles, D. M. (1994), “Total quality management: an overview”, in Dale, B. G. (Ed.), Managing quality, Prentice Hall International, Herts, pp. 3-40.

Davis, D. and Fisher, T. J. (1994), "The pace of change: A case study of the development of a total quality organization”, International Journal of Quality \& Reliability Management, Vol. 11, No. 8, pp. 5-18.

Deming, W. E. (1982), Quality, productivity and competitive position, Massachusetts Institute of Technology, Cambridge.

Deming, W. E. (1986), Out of the crisis, Massachusetts Institute of Technology, Cambridge. 
Drensek, R. A. and Grubb, F. B. (1995), “Quality quest: one company's successful attempt at implementing TQM”, Quality Progress, Vol. 28, No. 9, pp. 91-95.

Ebrahimpour, M. (1988), “An empirical study of American and Japanese approaches to quality management in the United States", International Journal of Quality \& Reliability Management, Vol. 5, No. 5, pp. 5-24.

English, L. P. (1996), "Help for data-quality problems”, Informationweek, No. 600, pp. 53-62.

Feigenbaum, A. V. (1956), "Total quality control", Harvard Business Review, Vol. 34, No. 6, pp. 93-101.

Feigenbaum, A. V. (1961), Total quality control, McGraw-Hill, New York.

Feigenbaum, A. V. (1991), Total quality control. 3rd ed., McGraw-Hill, New York.

Flynn, B. B., Schroeder, R. G. and Sakakibara, S. (1994), "A framework for TQM research and an associated measurement instrument”, Journal of Operations Management, Vol. 11, No. 4, pp. 339-366.

Garvin, D. A. (1986), "Quality problems, policies, and attitudes in the United States and Japan: an exploratory study”, Academy of Management Journal, Vol. 29, No. 4, pp. 653-673.

Garvin, D. A. (1988), Managing quality, The Free Press, New York.

Godfrey, G., Dale, B., Marchington, M. and Wilkinson, A. (1997), "Control: a contested concept in TQM research”, International Journal of Operations \& Production Management, Vol. 17, No. 6, pp. 558-573.

Grandzol, J. R. and Traaen, T. (1995), "Using mathematical programming to help supervisors balance workloads”, Interfaces, Vol. 25, No. 4, pp. 92-103.

Hackman, J. R. and Wageman, R. (1995), “Total quality management: Empirical, conceptual, and practical issues”, Administrative Science Quarterly, Vol. 40, No. 2, pp. 309-342.

Hauser, J. R. and Clausing, D. (1988), “The house of quality”, Harvard Business Review, Vol. 66, No. 3, pp. 63-73.

Ishikawa, K. (1985), What is total quality control? The Japanese way, Prentice-Hall, New York.

Ishikawa, K. (1989), "How to apply companywide quality control in foreign countries”, Quality Progress, Vol. 22, No. 9, pp. 70-74.

Ishikawa, K. (1990), Introduction to quality control, 3A Corporation, Tokyo.

Juran, J. M., Gryna, F. M. and Bingham, R. S. (Eds.) (1974), Quality control handbook, (3rd. ed.), McGraw-Hill, New York.

Juran, J. M. and Gryna, F. M. (Eds.) (1988), Quality control handbook, (4th. ed.), McGraw-Hill, New York.

Juran, J. M. (1988), Juran on planning for quality, Free Press, New York.

Juran, J. M. (Ed.) (1995), A history of managing for quality, ASQC Quality Press, Milwaukee, Wisconsin.

Maslow, A. H. (1954), Motivation and personality, Harper and Bros., New York.

Monden, Y. (1983), Toyota production system, Institute of Industrial Engineers, Atlanta.

McGregor, D. N. (1960), The human side of enterprise, McGraw-Hill, New York.

Milakovich, M. E. (1991), "Total Quality Management in the Public Sector", National Productivity Review, Vol. 10, No. 2, pp. 195-213.

Ouchi, W. G. (1981), Theory Z. How American business can meet the Japanese challenge, Addison-Wesley Publishing, USA.

Pollock, S. (1993), “The KISS principle works”, Journal for Quality \& Participation, Vol. 16, No. 7, pp. 90-92. 
Powell, T. C. (1995), “Total quality management as competitive advantage: a review and empirical study”, Strategic Management Journal, Vol. 16, No. 1, pp. 15-37.

Roethlisberger, F. J. and Dickson, W. J., (1939), Management and the worker, Harvard University Press, Cambridge, MA.

Rago, W. V. (1994), “Adapting total quality management (TQM) to government: Another point of view”, Public Administration Review, Vol. 54, No. 1, pp. 6164.

Saraph, J. V., Benson, P. G. and Schroeder, R. G. (1989), “An instrument for measuring the critical factors of TQM”, Decision Sciences, Vol. 20, No. 4, pp. 810-829.

Schay, B. W. (1993), "In search of the holy grail: Lessons in performance management”, Public Personnel Management, Vol. 22, No. 4, pp. 649-668.

Shewhart, W. A. (1931), Economic control of quality manufactured product, Van Nostrand, New York.

Shingo, S. (1986), Zero quality control: source inspection and the poka-yoke system, Productivity Press, Cambridge, Mass.

Stuelpnagel, T. R. (1993), "Deja vu: TQM returns to Detroit and elsewhere”, Quality Progress, Vol. 26, No. 9, pp. 91-95.

Taguchi, G. (1986), Introduction to quality engineering, Asian Productivity Organization, Tokyo.

Tamimi, N. and Gershon, M. (1995), “A tool for assessing industry TQM practice versus the Deming philosophy”, Production \& Inventory Management Journal, Vol. 36, No. 1, pp. 27-32.

Tucker, F. G., Zivan, S. M. and Camp, R. C. (1987), "How to measure yourself against the best”, Harvard Business Review, Vol. 65, No. 1, pp. 8-10. 


\begin{tabular}{|c|c|c|c|c|c|}
\hline DIMENSIONS & DESCRIPTION & Dale et al. (1994) & Saraph et al. (1989) & Flynn et al. (1994) & Ahire et al. (1996) \\
\hline $\begin{array}{l}\text { Top management } \\
\text { support }\end{array}$ & $\begin{array}{l}\text { Top management commitment is one of the major determinants of successful } \\
\text { TQM implementation. Top management has to be the first in applying and } \\
\text { stimulating the TQM approach, and they have to accept the maximum } \\
\text { responsibility for the product and service offering. Top management also has } \\
\text { to provide the necessary leadership to motivate all employees. }\end{array}$ & $\begin{array}{l}\text { Commitment and } \\
\text { leadership of the chief } \\
\text { executive officer } \\
\text { Planning and } \\
\text { organisation }\end{array}$ & $\begin{array}{l}\text { Role of divisional top } \\
\text { management and } \\
\text { quality policy }\end{array}$ & $\begin{array}{l}\text { Top management } \\
\text { support }\end{array}$ & $\begin{array}{l}\text { Top management } \\
\text { commitment }\end{array}$ \\
\hline Customer relationship & $\begin{array}{l}\text { The needs of customers and consumers and their satisfaction have always to } \\
\text { be in the mind of all employees. It is necessary to identify these needs and } \\
\text { their level of satisfaction. }\end{array}$ & Culture change & -- & Customer involvement & Customer focus \\
\hline Supplier relationship & $\begin{array}{l}\text { Quality is a more important factor than price in selecting suppliers. Long- } \\
\text { term relationship with suppliers has to be established and the company has } \\
\text { to collaborate with suppliers to help improve the quality of products/services. }\end{array}$ & Culture change & $\begin{array}{l}\text { Supplier quality } \\
\text { management }\end{array}$ & Supplier involvement & $\begin{array}{l}\text { Supplier quality } \\
\text { management }\end{array}$ \\
\hline Workforce management & $\begin{array}{l}\text { Workforce management has to be guided by the principles of: training, } \\
\text { empowerment of workers and teamwork. Adequate plans of personnel } \\
\text { recruitment and training have to be implemented and workers need the } \\
\text { necessary skills to participate in the improvement process. }\end{array}$ & $\begin{array}{l}\text { Culture change } \\
\text { Education and training } \\
\text { Teamwork }\end{array}$ & $\begin{array}{l}\text { Training } \\
\text { Employee relations }\end{array}$ & Workforce management & $\begin{array}{l}\text { Employee empowerment } \\
\text { Employee training }\end{array}$ \\
\hline $\begin{array}{l}\text { Employee attitudes and } \\
\text { behaviour }\end{array}$ & $\begin{array}{l}\text { Companies have to stimulate positive work attitudes, including loyalty to the } \\
\text { organisation, pride in work, a focus on common organisational goals and the } \\
\text { ability to work cross-functionally. }\end{array}$ & Involvement & - & $\begin{array}{l}\text { Quality improvement } \\
\text { rewards }\end{array}$ & Employee involvement \\
\hline Product design process & $\begin{array}{l}\text { All departments have to participate in the design process and work together } \\
\text { to achieve a design that satisfies the requirements of the customer, according } \\
\text { to the technical, technological and cost constraints of the company. }\end{array}$ & -- & Product/service design & Product design & $\begin{array}{r}\text { Design quality } \\
\text { management }\end{array}$ \\
\hline $\begin{array}{c}\text { Process flow } \\
\text { management }\end{array}$ & $\begin{array}{l}\text { Housekeeping along the lines of the } 5 \mathrm{~S} \text { concept. Statistical and nonstatistical } \\
\text { improvement instruments should be applied as appropriate. Processes need } \\
\text { to be mistake proof. Self inspection undertaken using clear work instructions. } \\
\text { The process has to be maintained under statistical control. }\end{array}$ & $\begin{array}{l}\text { Use of tools and } \\
\text { techniques }\end{array}$ & $\begin{array}{r}\text { Process management / } \\
\text { operating procedures }\end{array}$ & Process management & SPC usage \\
\hline $\begin{array}{l}\text { Quality data and } \\
\text { reporting }\end{array}$ & $\begin{array}{l}\text { Quality information has to be readily available and the information should } \\
\text { be part of the visible management system. Records about quality indicators } \\
\text { have to be kept, including scrap, rework and cost of quality. }\end{array}$ & $\begin{array}{l}\text { Measurement and } \\
\text { feedback }\end{array}$ & $\begin{array}{l}\text { Quality data and } \\
\text { reporting }\end{array}$ & Feedback & $\begin{array}{l}\text { Internal quality } \\
\text { information usage }\end{array}$ \\
\hline $\begin{array}{l}\text { Role of the quality } \\
\text { department }\end{array}$ & $\begin{array}{l}\text { Quality department need access to top management and autonomy and also } \\
\text { has to combine the work of other departments. }\end{array}$ & -- & $\begin{array}{l}\text { Role of the quality } \\
\text { department }\end{array}$ & -- & -- \\
\hline Benchmarking & A benchmarking policy for key processes should be in place. & -- & -- & -- & Benchmarking \\
\hline
\end{tabular}




\begin{tabular}{|c|c|c|c|c|c|c|c|}
\hline YEAR & TQM & TQM \% & QM & QM \% & TQ & TQ \% & TOTAL \\
\hline 86 & 4 & 0.0093 & 27 & 0.063 & 27 & 0.063 & 42824 \\
\hline 87 & 7 & 0.0168 & 27 & 0.0648 & 48 & 0.1152 & 41672 \\
\hline 88 & 10 & 0.0211 & 36 & 0.0758 & 58 & 0.1221 & 47490 \\
\hline 89 & 44 & 0.096 & 54 & 0.1178 & 90 & 0.1963 & 45853 \\
\hline 90 & 95 & 0.1861 & 56 & 0.1097 & 123 & 0.2409 & 51054 \\
\hline 91 & 241 & 0.3996 & 91 & 0.1509 & 235 & 0.3896 & 60313 \\
\hline 92 & 453 & 0.6772 & 108 & 0.1615 & 301 & 0.45 & 66890 \\
\hline 93 & 720 & 0.5608 & 98 & 0.0763 & 612 & 0.4767 & 128386 \\
\hline 94 & 592 & 0.424 & 91 & 0.0652 & 610 & 0.4369 & 139608 \\
\hline 95 & 434 & 0.2746 & 57 & 0.0361 & 565 & 0.3575 & 158046 \\
\hline 96 & 248 & 0.1441 & 82 & 0.0476 & 383 & 0.2225 & 172156 \\
\hline 97 & 122 & 0.0912 & 84 & 0.0628 & 203 & 0.1517 & 133810 \\
\hline
\end{tabular}


Table 3. Important events in the development of TQM.

1924-1932. 1924.

Hawthorne studies demonstrated the importance of the social and psychological climate in work.

Shewhart developed statistical process control.

The Bell Telephone began to apply statistical control methods.

Mid 1940s.

The American army pushed the use of sampling methods during World War II. 1950s.

A large number of attempts at work improvement were undertaken (e.g. job enrichment, work redesign, 1950. participative management, quality of work life and worker involvement).

1951.

First visit of Deming to Japan.

Creation of "Deming Application Prize" in Japan. 1954.

First edition of Juran's “Quality Control Handbook”.

First visit of Juran to Japan.

Maslow's theories about human needs. 1960.

Liberalisation of economy in Japan with pressure to improve quality to compete with foreign companies.

McGregor's $\mathrm{X}$ and $\mathrm{Y}$ theories.

1961. 1962.

First edition of Feigenbaum's “Total Quality Control”.

The idea of quality circles appeared in the first issue of the Japanese journal "Quality Control for the Foreman".

Late 1960s and early 1970s. 1972.

The pressure of Japanese companies began to be felt in American companies.

1973.

QFD was developed at Mitsubishi’s Kobe shipyard site.

After the 1973 oil crisis the JIT system was adopted by a vast number of Japanese companies. A small number of American and European companies began to apply this system in the 1980s.

Mid 1970s.

Quality circles began to be widely introduced in the USA, the first quality circle programme was launched in Lockheed in 1974 and in the UK it was Rolls Royce who introduced the concept in 1979. 1979.

First edition of Crosby's “Quality is Free”.

Xerox Corp. started to apply the benchmarking concept to processes.

Publication of the BS5750 quality management series.

1980.

A NBC television documentary about the "Japanese miracle” proposed Deming as a key element in this miracle.

1981.

1982.

Ouchi's Z theory. 1983.

First edition of Deming’s “Quality, productivity and competitive position”.

"Quality on the line”, published by Garvin in Harvard Business Review analysed the differences between Japanese and American companies, showing some of the reasons for the better performance of the former.

A paper about Taguchi's design of experiments is published in Harvard Business Review (Taguchi and 1985. Clausing, 1983).

The Naval Air Systems Command named its Japanese-style management approach "total quality management”. 1986. 1987.

First edition of Deming's "Out of the crisis”. It became a best seller. 1987.

First edition of ISO 9000 quality management system series.

Publication of the Malcolm Baldridge National Quality Award. 


\begin{tabular}{|c|c|c|c|c|c|}
\hline DIMENSIONS & DEMING & JURAN & ISHIKAWA & FEIGENBAUM & CROSBY \\
\hline TOP MANAGEMENT SUPPORT & No important differences & No important differences & No important differences & No important differences & No important differences \\
\hline CUSTOMER RELATIONSHIP & No important differences & No important differences & No important differences & No important differences & No important differences \\
\hline SUPPLIER RELATIONSHIP & No important differences & $\begin{array}{l}\text { He considers that "for } \\
\text { important purchases it is } \\
\text { well to use multiple sources } \\
\text { of supply" (Juran, 1974, p. } \\
\text { 10-5). }\end{array}$ & $\begin{array}{l}\text { He considers that the } \\
\text { number of suppliers has to } \\
\text { be two. Only one supplier } \\
\text { can be dangerous. }\end{array}$ & $\begin{array}{l}\text { The importance of long term } \\
\text { relationships and reduction } \\
\text { in the number of suppliers is } \\
\text { not considered. }\end{array}$ & No important differences \\
\hline WORKFORCE MANAGEMENT & $\begin{array}{l}\text { Except for the importance of } \\
\text { training, he scarcely } \\
\text { considers this factor. For } \\
\text { him, improvement is } \\
\text { basically a managers' work. }\end{array}$ & No important differences & $\begin{array}{l}\text { He emphasises the } \\
\text { importance of quality } \\
\text { circles. }\end{array}$ & $\begin{array}{l}\text { Empowerment and } \\
\text { teamwork are scarcely } \\
\text { considered. }\end{array}$ & $\begin{array}{l}\text { He does not consider } \\
\text { empowerment }\end{array}$ \\
\hline EMPLOYEE ATTITUDES AND BEHAVIOUR & $\begin{array}{l}\text { Motivational campaigns are } \\
\text { useless. }\end{array}$ & $\begin{array}{l}\text { Motivation does not assure a } \\
\text { zero defects production } \\
\text { (Juran, 1974, p. 18-8). }\end{array}$ & No important differences. & No important differences. & No important differences \\
\hline PRODUCT DESIGN PROCESS & Not considered & No important differences & No important differences. & No important differences. & Not considered \\
\hline PROCESS FLOW MANAGEMENT & $\begin{array}{l}\text { He focuses on the need of } \\
\text { maintain the process under } \\
\text { statistical control. He } \\
\text { criticises the zero defects } \\
\text { approach and sampling } \\
\text { inspection. }\end{array}$ & No important differences & No important differences. & No important differences. & $\begin{array}{l}\text { He focuses on the need of } \\
\text { achievement of zero defects } \\
\text { through prevention. }\end{array}$ \\
\hline QUALITY DATA AND REPORTING & Not considered & No important differences & No important differences. & Not considered. & No important differences \\
\hline ROLE OF THE QUALITY DEPARTMENT & No important differences & No important differences & $\begin{array}{l}\text { He emphasises the } \\
\text { involvement of all employees } \\
\text { in studying and promoting } \\
\text { quality control. It has not to } \\
\text { be a exclusive domain of } \\
\text { specialists. He does not make } \\
\text { any specific comment about } \\
\text { quality departments. }\end{array}$ & $\begin{array}{l}\text { He emphasises the need to } \\
\text { have a management function } \\
\text { whose only area of operation } \\
\text { is in the quality control jobs. } \\
\text { He considers that, although } \\
\text { quality is everybody's job, it } \\
\text { may become nobody's job is } \\
\text { this department does not } \\
\text { exist. }\end{array}$ & No important differences \\
\hline BENCHMARKING & Not considered & Not considered & Not considered. & Not considered. & Not considered \\
\hline
\end{tabular}


